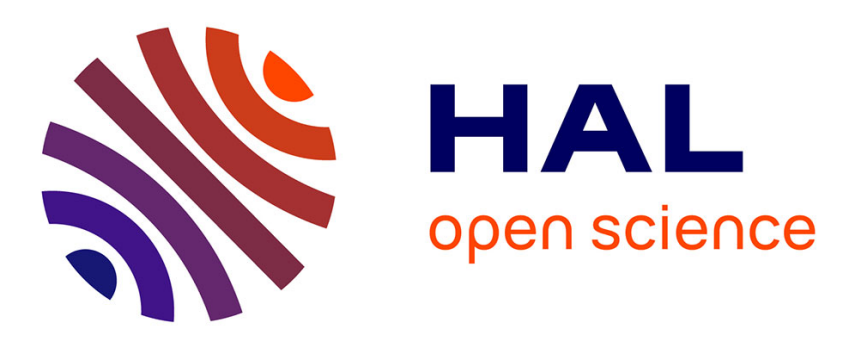

\title{
Board leadership and strategy involvement in small firms: A team production approach
}

Silke Machold, Morten Huse, Alessandro Minichilli, Mattias Nordqvist

\section{To cite this version:}

Silke Machold, Morten Huse, Alessandro Minichilli, Mattias Nordqvist. Board leadership and strategy involvement in small firms: A team production approach. Corporate Governance: An International Review, 2011, 19 (4), pp.368. 10.1111/j.1467-8683.2011.00852.x . hal-00625944

\section{HAL Id: hal-00625944 https://hal.science/hal-00625944}

Submitted on 23 Sep 2011

HAL is a multi-disciplinary open access archive for the deposit and dissemination of scientific research documents, whether they are published or not. The documents may come from teaching and research institutions in France or abroad, or from public or private research centers.
L'archive ouverte pluridisciplinaire HAL, est destinée au dépôt et à la diffusion de documents scientifiques de niveau recherche, publiés ou non, émanant des établissements d'enseignement et de recherche français ou étrangers, des laboratoires publics ou privés. 


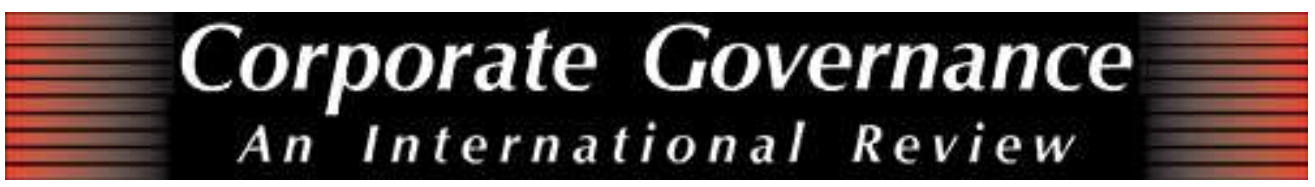

Board leadership and strategy involvement in small firms: A team production approach

\begin{tabular}{|r|l|}
\hline Journal: & Corporate Governance: An International Review \\
\hline Manuscript ID: & CGIR-2010-0172.R3 \\
\hline Manuscript Type: & Original Manuscript \\
\hline Keywords: & $\begin{array}{l}\text { Board Leadership < Board of Director Mechanisms, Board of } \\
\text { Director Mechanisms, Corporate Governance Theories }\end{array}$ \\
\hline \multicolumn{2}{|c}{} \\
\hline
\end{tabular}

\section{SCHOLARONE ${ }^{\text {m }}$ \\ Manuscripts}


BOARD LEADERSHIP AND STRATEGY INVOLVEMENT IN SMALL FIRMS: A TEAM PRODUCTION APPROACH

\begin{abstract}
Manuscript Type: Empirical

Research Question/Issue: Boards' involvement in strategy is generally seen to be an indicator of board effectiveness but less is known about the relationship between board leadership and strategy involvement, especially in small firms. This study analyses board leadership from a team production perspective as an antecedent to board strategy involvement in small firms.

Research Findings/Insights: Using survey data from 140 small firms in Norway collected in two different time periods, we demonstrate that leadership behaviors and processes have a greater impact on boards' strategy involvement than structural leadership characteristics alone.

Theoretical/ Academic Implications: The study provides empirical support for a team production perspective on boards. Our data show that: 1) board members' knowledge, board development and board chairperson leadership efficacy positively influence boards' strategy involvement, and 2) chairperson leadership efficacy enhances boards' strategy involvement under structural conditions of combined CEO/chairperson leadership and changes in board composition. These findings expand the traditional understanding of structural leadership conditions.

Practitioner/Policy Implications: The study offers insights to small business owners and managers on how to improve the strategy involvement of boards. For policy makers, the study has implications for the content of codes of good governance practice relevant to small firms, specifically in relation to board development initiatives and board evaluations.
\end{abstract}




\section{INTRODUCTION}

Most research on corporate governance and boards has focused theoretically and empirically on large corporations (Daily, Dalton \& Cannella, 2003; Gabrielsson \& Huse, 2004). Whilst research in small firms has grown substantially, relatively limited attention has thus far been paid to their boards and governance structures (Fiegener, 2005; Fiegener, Brown, Dreux \& Dennis, 2000a, 2000b; Gabrielsson \& Winlund, 2000). There is, however, an emerging consensus that boards in small firms may constitute an important organizational asset (Certo, Covin, Daily \& Dalton, 2001; Gabrielsson, 2007), that boards can add an important strategic dimension to small firms (Brunninge, Nordqvist \& Wiklund, 2007; Fiegener, 2005; Zahra, Filatotchev, \& Wright, 2009) and that small firm board and governance structures can influence firm value creation (Certo, Daily \& Dalton, 2001; Huse, 2000).

Extant research identifies both differences and similarities in corporate governance and boards in large and small firms. In large corporations, assumptions about separation of ownership and control along with divergent utilities of managers and shareholders sharpened the focus of research and governance practice on the monitoring and control role of boards (Jensen \& Meckling, 1976, Daily et al., 2003; Zattoni \& Cuomo, 2010). Whilst agency problems are also relevant to the small firm context, decision-making and control structures here are less complex and diffuse compared to large firms resulting in a comparatively diminished boards' monitoring role (Daily \& Dalton, 1993; Fama \& Jensen, 1983). The type and content of boards' service and strategy tasks also vary between small and large firms (Zahra \& Pearce, 1989), and at different stages of small firms' life cycle (Lynall, Golden \& Hillman, 2003). Finally, the impact of founders and/or key entrepreneurs on boards and governance may be greater in small firms compared to large ones (Arthurs, Busenitz, 
Hoskisson \& Johnson, 2009; Nelson, 2003). Recently, scholars have explored what makes boards active and effective in task performance, including research on the range of tasks boards perform (Pugliese et al., 2009; Van den Heuvel, Van Gils \& Voordeckers, 2005). In trying to answer questions about the determinants of board effectiveness, researchers have increasingly paid attention to board team processes and behaviors rather than structural characteristics of boards alone (Finkelstein \& Mooney, 2003; Forbes \& Milliken, 1999), using direct observations and/or primary data rather than relying on traditional archival methods.

Focusing on board team processes, we investigate the effects of board leadership in small firms on board strategy involvement. Only a few studies have examined the role of board leadership in small firms and these tended to explore the antecedents and performance outcomes of structural leadership characteristics such as CEO duality (Daily \& Dalton, 1992; 1993; Daily, McDougall, Covin \& Dalton, 2002). Our study extends that body of knowledge by drawing on a team production approach as a novel theoretical perspective to investigate board leadership processes in small firms. By focusing on how leadership relates to small firm boards' strategy involvement, this paper also aims to respond to calls for more theoretical and empirical research on determinants of strategy involvement (Fiegener, 2005; Kim, Burns \& Prescott, 2009).

The article is structured as follows. Following a brief introduction to the literature on board strategy involvement in small firms, we outline our theoretical approach and derive hypotheses. We then discuss the methods used including our sample, variable measurements, data collection and analysis methods. Following the presentation of our results, we discuss their implications for research and practice before concluding with areas for further research. 


\section{THEORETICAL BACKGROUND}

\section{Board Strategy Involvement in Small Firms}

Research on boards' involvement in strategy has been prolific (Judge \& Zeithaml, 1992; McNulty \& Pettigrew, 1999; Golden \& Zajac 2001; Pugliese et al., 2009) for a number of reasons. First, boards' involvement in strategy is increasingly viewed as a core contribution to firms' value creation processes (Demb \& Neubauer, 1990; Judge \& Zeithaml, 1992; Pugliese et al, 2009) despite some evidence to the contrary (Hitt, Harrison, \& Ireland, 2001). Hence, research into boards' strategy involvement has been motivated by the need to understand the links between board and firm performance (Zahra \& Pearce, 1989; Baysinger \& Hoskisson, 1990; Westphal \& Fredrickson, 2001). A second and related reason is that the debate on active versus passive boards has coalesced around boards' strategy involvement as a key differentiator between these (Castro, de la Concha, Gravel \& Perinan, 2009, Pettigrew, 1992; Rindova, 1999). McNulty and Pettigrew (1999), for example, argue that an active board does not just ratify and control strategy, it is also involved in formulating strategic decisions as well as defining and shaping which decisions are to be taken in particular contexts. Thus, boards' strategy involvement may be seen as a key indicator of board performance and effectiveness (Stiles, 2001). Third, boards' strategy involvement is a complex multi-dimensional construct and has been approached from a range of theoretical perspectives (Carpenter \& Westphal, 2001; Pugliese et al., 2009). This theoretical pluralism has presented both opportunities and challenges for empirical research and the practical implications derived from it (Pugliese et al., 2009). 
Despite the impressive advancements in knowledge in boards' strategy involvement, some unanswered questions remain. Not only is the empirical evidence on boards' strategy involvement inconclusive, there is a lack of empirical studies investigating the phenomenon in contexts other than large Anglo-American boards. Some notable exceptions notwithstanding (Fiegener, 2005; Gabrielsson \& Winlund, 2000; Judge \& Zeithaml, 1992), we lack knowledge on antecedents of boards' strategy involvement in small firms. Entrepreneurship and small business scholars have long called for research not only on the content but also the process of strategic decision-making in small firms (Dess, Lumpkin, \& McGee, 1999; Sandberg, 1992). Further, the role of teams and leadership in strategic decision-making processes in small firms is not yet fully understood (West, 2007). This paper builds on team production approach to boards and governance (Blair \& Stout, 1999; Kaufman \& Englander, 2005) to address these gaps.

\section{Board Dynamics in Small Firms: A Team Production Approach}

Small firms are often characterized by concentrated ownership, and the appropriateness of agency theory as a theoretical lens in such contexts has been questioned (Schulze, Lubatkin \& Dino, 2001; Uhlaner, Floren \& Geerlings, 2007). When relaxing assumptions about managerial opportunism and the separation of ownership and control, we need alternative theoretical perspectives to explain governance phenomena and board behaviors (Roberts, McNulty \& Stiles, 2005). One such alternative is the team production theory of the firm (Blair \& Stout, 1999; Kaufman \& Englander, 2005). The seeds of team production theory sprang from microeconomics when Alchian and Demsetz sought to explain cooperative behavior of individuals in work teams vis-à-vis opportunism and shirking, and the emergence 
of hierarchies in response to team production problems (Alchian \& Demsetz, 1972; Blair \& Stout, 1999). Whilst the micro-economists provided the basic tenets, it was the later contributions from other disciplines, including law and sociology, that fleshed out team production theory (Blair \& Stout, 1999; Blair, 2005). In the contemporary team production perspective, firms are conceptualized as a nexus of team-specific assets, invested by shareholders, board members, managers, employees, and other stakeholders who hope to profit from team production (Blair \& Stout, 1999; Gabrielsson, Huse \& Minichilli, 2007; Kaufman \& Englander, 2005). As such, team production theory has resonance with resource-dependency theory and a stakeholder perspective, but resolves the decision-making and rent-allocation ambiguities inherent in these theoretical approaches by introducing the concept of a mediating hierarchy (Blair \& Stout, 1999; Kaufman \& Englander, 2005). Instead of explicitly contracting with each other in order to determine their share in team production, team members surrender decision-making powers on the allocation of duties and rewards to a mediating hierarchy. In doing so, the mediating hierarch's function further extends to "encouraging firm-specific investment in team production by mediating disputes among team members..." (Blair \& Stout, 1999: 772). In a firm perspective, the mediating hierarchy function is performed by the board which at the apex of the firm's decision-making mediates between all team members that have invested firmspecific resources in order to encourage team production (Blair \& Stout, 1999). Consistent with Blair and Stout's (1999) notion of several levels of mediating hierarchies in firms, the board in itself is also a team that co-produces values (Forbes \& Milliken, 1999). In countries with unitary board structures, the board comprises of both executive (or inside) and non-executive (outside) directors, each one of which brings different knowledge and skills to the board team as well as representing 
different interest groups on the board. In the context of the board, therefore, the mediating hierarchy role theoretically rests with the board chairperson (Kaufman \& Englander, 2005).

In the context of small firms, the overlap between ownership and management, the lack of a formalized managerial structure, as well as the need to bring critical resources into the firm (Arthurs et al., 2009; Cowling, 2003) make the team production approach a useful theoretical lens for understanding boards, especially the determinants of strategic involvement of boards. Following the logic of team production theory, boards are viewed as cooperative teams that contribute to firms' value creation through their strategy involvement. Each board member brings specific and firm-relevant knowledge to the team, a key characteristic of team production approaches (Kaufman \& Englander, 2005). Board leadership is about effectively facilitating the presence and the use of firm-relevant knowledge and skills of board members (Huse, 2007). Further, boards are social systems, the effectiveness of which is determined by how board members share knowledge and interact (Forbes \& Milliken, 1999; Leblanc, 2005). Board leadership therefore also includes the design of effective interactions in boardrooms by means of rules and instructions as well as having skilled chairpersons exhibiting leadership behaviors.

To summarize, following a team production perspective we argue that board leadership is not a single-dimensional but a multi-dimensional construct. It includes processes for ensuring board members bring relevant knowledge to the boardroom, the design of interactions that facilitate the use of knowledge and skills, as well as chairperson leadership behaviors that maximize team production. In that line of argument, board leadership is a major determinant of board strategy involvement and 
a central mechanism to bring out the board's value creating potential (Gabrielsson et al., 2007; Leblanc, 2005).

\section{Board Members' Knowledge}

A key issue of board leadership is to ensure that board members have relevant knowledge (Forbes \& Milliken, 1999; Hillman \& Dalziel, 2003). The provision of knowledge and skills may directly influence firm's value creating capabilities, especially if such knowledge is firm- and industry-specific, including knowledge of critical technology and industry's characteristics, competitors' main features, and product/market developments (Kaufman \& Englander, 2005). Furthermore, board members' knowledge can prevent 'process losses' associated with highly interdependent and episodic teams and help board members to mutually build on each others' professionalisms (Forbes \& Milliken, 1999). In other words, board members 'must elicit and respect each others' expertise, build upon each others' contributions, and seek to combine their insights in creative, synergistic ways' (Forbes \& Milliken, 1999: 496).

Boards' knowledge and skills are particularly relevant in small firms for two reasons. First, small firms are typically characterized by a scarcity of resources, especially financial and managerial ones (Brunninge et al., 2007; Zahra \& Filatotchev, 2004). Board members' knowledge and skills that are firm-specific can therefore supplement the firms' internal knowledge and skills base provided by managers. Board members' knowledge and skills can also be a way to secure the provision of advice and new ideas more cost efficiently compared to hiring external consultants. Second, small firms often exhibit a dominance of entrepreneurialism over managerialism, with emphasis on action orientation and real-time strategies 
Hypothesis 1: There is a positive relationship between board members' knowledge and board strategy involvement in small firms.

\section{Board Development}

The team production approach highlights the problems of shirking and the need to put board members' knowledge and skills to use (Blair \& Stout, 1999; Kaufman \& Englander, 2005). The presence of knowledge per se does not imply that board members will use their knowledge (Forbes \& Milliken, 1999; Zona \& Zattoni, 2007). There is thus a need for board leadership and board development to ensure that the knowledge and skills are properly used (Demb \& Neubauer, 1992; Zahra \& Pearce, 1989). We define board development as the processes which facilitate board interactions, board working style and utilization of board member's knowledge. As 
such, board development consists of regular board development programs, board instructions and board evaluations to increase board involvement (Conger, Finegold \& Lawler, 1998; Demb \& Neubauer, 1992; Lorsch, 1995). The practice of such board development allows board members to get involved in various board activities and tasks (Demb \& Neubauer, 1992). Further, such initiatives are a way of turning a collection of individual directors into the working group of a board team (Leblanc, 2005), in other words, facilitating team production. Consequently, the process of board development is believed to exert a strong influence on board task performance (Gabrielsson \& Winlund, 2000).

Board development is particularly important in small firms for three related reasons. First, small firms are often characterized by a lack of formal structures and a dominance of informal processes (Uhlaner, Wright \& Huse, 2007). While informality may give flexibility, it can also increase uncertainty among board members and centralize decision-making in a way that hampers long-term strategic development. Formal board development processes can thus give structure to the strategic process in small firms and facilitate a greater involvement by board members. Second, governance in small firms is often characterized by role integration (Johannisson \& Huse, 2000) and division between various governance tasks are not always evident (Cowling, 2003). In small firm boards, formal instructions and evaluations may help to define board members' tasks and to clarify the relationship between the chairperson, the board members and the top management (Conger et al., 1998; Gabrielsson \& Winlund, 2000). Third, following the team production logic, board development processes are essential in order to transform a collection of individuals into a team that is collectively involved in strategic decisions. Theoretically and empirically, this logic is heightened in a small firm context where we are more likely 
to encounter small boards led by idiosyncratic entrepreneurs inclined towards individual actions and behaviors (Arthurs et al., 2009; Fiegener, 2005; West, 2007). We therefore hypothesize that:

Hypothesis 2: There is a positive relationship between board development and board strategy involvement in small firms.

\section{The Chairperson's Leadership Efficacy}

The individual who has the greatest ability to shape board leadership is possibly the board chairperson (Leblanc, 2005). Roberts et al. (2005) argued that the role of the board chairpersons is "vital to the board members' engagement in various ways", and "their own conduct does much to set the culture of the board" (p. S15). As proposed above, the board is a social system and it contains board members with a mix of personalities, skills and motivation that may influence how they individually and collectively engage in board task performance (Huse, 2007). The chairperson's leadership behaviors have the potential to influence board effectiveness.

The basic premise of the team production approach is that the productivity of any board member is greater as a result of the interaction with other board members (Alchian and Demsetz, 1972). To secure positive team outcomes, the board chairperson is expected to lead individual board team members in order to “... meld the board into a cohesive group, and to make each individual director feel that he or she is equal" (Huse, 2007: 201). As Leblanc (2005) pointed out, it is doubtful that a strong, engaged board will have a weak chairperson or that an ineffective board will have a strong and skilled leader. In practice, board chairpersons range from effective to neglectful, from domineering to self-serving. 
The board chairperson's leadership efficacy is particularly relevant in the light of the peculiar characteristics of the board of directors. Since the board is a group with a mix of personalities and relationships, there is increasing amount of interest in how the chairperson actually leads the board's work (Furr \& Furr, 2005; Leblanc \& Gillies, 2005; Letendre, 2004; Dulewicz, Gay, \& Taylor, 2007). While the CEO leads employees in everyday company settings, the board chairperson is the one motivating and leading the board. Hence, the chairperson's role can be portrayed as that of an orchestrator of an elite group of individuals which meet episodically (Forbes \& Milliken, 1999), and whose competences and knowledge need to be coordinated, integrated and developed towards team efficacy (Wu, Tsui \& Kinicky, 2010).

From a team production perspective, the chairperson's leadership efficacy may be an especially important determinant of board strategy involvement in small firms. Boards in small firms are characterized by a relative scarcity of resources, or inputs to team production (Cowling, 2003), because of their small size and common dominance of internal board members. Daily and Dalton (1992) argue that board leadership is likely to be especially visible and important for coordinating the scarce resources towards creating an effective board in small firms. For instance, in addition to leading the internal board work, chairpersons in small firms are particularly important in securing efficient management of external network contacts (Borch \& Huse, 1993). This includes gaining the legitimacy that small firms sometimes lack compared to their larger counterparts (Davis \& Pett, 2000; Stinchcombe, 1965). Further, there is typically a greater amount of concentration of power in the hands of one or a few individuals in small firm boards. These individuals tend to be both owners and board members in small firms (Brunninge et al., 2007; Eddleston, 2008). To facilitate board members' involvement in strategy in the midst of this concentration of power in small 
Hypothesis 3: There is a positive relationship between the board chairperson's leadership efficacy and board strategy involvement in small firms.

\section{Moderating Influences of Board Structure}

We argued that leadership efficacy of the board chairperson is of particular importance in a team production perspective. Given this prominence, we further explore the importance of chairperson leadership under two contingent structural conditions typical for small firms. The first is when there is CEO duality, i.e. when the CEO of the firm is also the board chairperson; the second is when there has been a recent change in board composition.

A main theme in the literature about board leadership is CEO duality (Dalton, Daily, Ellstrand \& Johnson. 1998). Advocates of CEO duality argue that it is useful to reinforce the leadership structure of the firm by providing 'unity of command' and mitigating ambiguity about key responsibilities (Anderson \& Anthony, 1986). However, agency-theoretic arguments imply a separation of the two positions (Coles \& Hesterly, 2000; Fama \& Jensen, 1983; Finkelstein \& D’Aveni, 1994; Jensen \& Meckling, 1976). The CEO duality discussion has been developed in the large firm context where monitoring and control tasks of the board have been prioritized, often 
under pressure from shareholder activists distrustful of managerial behavior (Rechner \& Dalton, 1991). Yet even here agency-theoretic arguments for the separation of CEO/chairperson roles are disputed. Theoretically, stewardship theory contests both the assumptions and prediction of agency theory and proposes instead CEO/chair duality (Davis, Schoorman \& Donaldson, 1997; Muth \& Donaldson, 1998). Empirically, there is no conclusive evidence of any systematic relationship between CEO/chairperson leadership structure and firm performance (Dalton et al., 1998). Conceptually, the CEO duality debate is pre-occupied with the monitoring tasks of boards with relatively less attention being paid to boards' strategic involvement (Conyon \& Peck, 1998; Tuggle, Sirmon, Reutzel \& Bierman, 2010; Uhlaner, Wright \& Huse, 2007).

Contextually, small firms differ from the large ones in several important ways, including more concentrated ownership structures and role integration, making CEO duality a much more common phenomenon in the small business setting (Cowling, 2003; Daily \& Dalton, 1993). Recent research into CEO duality in firms with high levels of strategic, or concentrated, ownership supports the argument that in such contexts duality positively impacts firm performance (Chahine \& Tohme, 2010).

Our argument, however, is not about CEO duality per se, rather we are interested in how the presence of CEO duality affects the relationship between chair leadership efficacy and board strategy involvement. We proposed that in team production theory, the leadership efficacy of the chairperson, that is chairpersons' behaviors aimed at melding the board team, is positively related to boards' strategy involvement. An additional theoretical argument from team production is the need for a mediating hierarch to resolve actual or potential decision-making ambiguities (Blair \& Stout, 1999). Under conditions of CEO/chairperson separation, this mediating 
Hypothesis 4: In small firms with CEO duality, the positive relationship between the leadership efficacy of the board chairperson and board strategy involvement will be strengthened.

A second contingent situation related to board leadership is that of recent changes in board composition. From a team production perspective a change in board composition, regardless of the nature (insider/outsider balance) of such a change, creates a discontinuity in the board team dynamics. New and old board members alike require socialization into the re-constituted team in order to develop trust, and to understand and accept the working style of the board. As a consequence, a change in board composition may temporarily reduce team production. We expect this argument to be particularly relevant in small firms. To a greater extent than in large firms, boards in small firms tend to be characterized by people who have close and trustbased ties to each other, such as family and friends (Brunninge et al., 2007). Boards in small firms also tend to be smaller in size than in large firms (Gabrielsson, 2007). In small firm boards composed of a small group of people with strong ties to each other, we can expect that routines are established with regard to the board's role in strategy (Johannison \& Huse, 2000). From a team production perspective, these two 
characteristics of small firm boards are likely to mean that a change in board composition constitutes a considerable emotional event for board members with implications for their ability to perform their roles (Brundin \& Nordqvist, 2008). In other words, the change in composition has a negative impact on board strategy involvement because the change is dramatic enough to disrupt the working style of board. Therefore, we hypothesize that:

Hypothesis 5: There is a negative relationship between recent changes in board composition and subsequent board strategy involvement in small firms.

Building on the previous arguments about the nature and impact of leadership efficacy in boards, firms that have experienced a recent change in board composition have a stronger need for a leader whose behaviors and skills ensure that the board continues to work as a cohesive team (Leblanc, 2005). A change in the board composition, regardless of its effects on the insider/outsider ratio in the board, accentuates the need for leadership efficacy to re-configure the boardroom culture and extend it to new board member(s) (Huse, 2007). From a team production perspective, the 'social side' of board work, for instance, to build personal relationships and to coach individual members to find their role in the new board and to make them feel confident to contribute is a key feature of the board chair's leadership efficacy.

We expect the social side of board leadership efficacy to be particular important to weaken the negative effect of changes in board composition in small firm boards. This is because boards in small firms are generally characterized by an informal working style based on personal relationships and close ties between members of the board (Daily \& Dalton, 1992; 1993). In other words, the role of the social interaction led by 
the board chairperson to build trust and confidence among board members becomes pivotal to facilitate board strategy involvement in small firms, since there are few formal routines to rely upon. Thus, whilst changes in board composition may have a negative effect on boards' strategy involvement (H5), we propose that this negative effect will be mitigated by the leadership efficacy of the board chairperson. We therefore hypothesize that:

Hypothesis 6: In small firms, the negative relationship between recent changes in board composition and subsequent board strategy involvement is positively moderated by the leadership efficacy of the board chairperson.

\section{METHODS}

\section{Sample and Data Collection}

The hypotheses are tested through a quantitative study based on survey data in Norway. The Norwegian governance system exhibits both similarities and differences to that found in other countries (Shleifer \& Vishny, 1997). Historically, the state had greater influence in business affairs compared to Anglo-American countries, and this continues to manifest itself in government ownership, especially of large listed companies, and a strong regulatory regime affecting governance including mandatory women and employee representation on boards. But there are also similarities. The Norwegian Code of Practice for Corporate Governance exhibits many commonalities to other international codes, including board structures and the division of responsibilities between boards, shareholders and management (NUES, 2010). Norway is also well known for its tradition of having small firms with active boards (Huse, 1990), and hence it is a particularly useful empirical setting for our research. 
The use of survey methods is motivated by the need to avoid reliance on secondary data as proxies for board processes, and follows calls to develop measures which try to capture actual board behavior (Forbes \& Milliken, 1999; Hambrick, von Werder \& Zajac, 2008). To this purpose, we designed a survey instrument based on established measures in the literature. Data were collected in two time-periods, 2004 and 2005, through an eight page questionnaire where responses were collected from CEOs and chairpersons. The original questionnaire was sent in 2004 to a random sample of 3,000 small Norwegian firms that had, according to the list of Market Select, between 5 and 50 employees, and sales between 5 million and 50 million Norwegian crowns (or between 1 million and 10 million USD at the then exchange rate). We based our definition of 'small' on the official EU definition whilst using a lower limit of 5 employees to exclude micro-enterprises (European Union, 2003).

Market Select is one of several agencies providing data drawn from the Public Norwegian Company databases at Bronnoysund, which contain all Norwegian firms. We used the small firm data subset from Market Select, based on our definition above. There was no ex ante indication of the existence of boards in these firms. Responses were received from 973 firms, and 498 of these declared the existence of a board of directors. Of those firms, only 347 provided complete responses on all the board- related survey measures we used in our analyses, and fitted our size definition. The first survey was followed up by a second survey in 2005, including both responding and non-responding firms to the original 2004 survey. From these, we further filtered out 'micro boards' (those with fewer than 3 board members) since team dynamics could not be sufficiently grasped here. Following the above criteria, 140 (identical) small firms with boards greater than 3 members replied to both the 2004 and 2005 surveys and these formed the final usable dataset. 
The data used were responses from CEOs on behalf of the entire board. Since it is traditionally difficult to gain access to process data on boards of directors (e.g. Daily et al., 2003; Pettigrew, 1992), governance studies incorporating primary data are usually based on a single respondent, typically the CEO (e.g. Pearce \& Zahra, 1991; Zahra, Neubaum \& Huse, 2000; Zhang, 2010). In line with previous studies, we consider the $\mathrm{CEO}$ as the best possible key informant because he/she is knowledgeable about the phenomena pertinent to our study, and better placed than other board members to report on these. Furthermore, having multiple responses in some specific circumstances can enhance the risk of constructing averaged measures which reflect divergence across reports, rather than representing the constructs being investigated (Kumar, Stern \& Anderson, 1993). In our case, we also collected responses from board chairpersons in the 2005 follow-up survey, but decided not to use these due to the nature of our research questions (re: chairperson leadership efficacy), and because using matched pairs would have reduced the size of our sample even further (49 matched cases remaining). However, we conducted additional validity checks by testing for correlations between the 2005 CEO and chairperson responses in two of the independent variables (board members' knowledge, and board development; chairperson efficacy was not tested for due to potential self-rating bias), and these were significant and positive.

In order to deal with common method bias (Doty \& Glick, 1998), we applied a number of procedural remedies in the instrument development and data collection phase (Podsakoff, MacKenzie, Lee \& Podsakoff, 2003). First, we protected the respondents' anonymity by assuring confidentiality of their responses in the cover letter that accompanied the survey. Second, we invested considerable time and effort in improving the scale items and reducing item ambiguity. All survey questions were 
short, specific and used simple words to avoid ambiguous and vague formulations (Dillman, 2000). To enhance the construct validity of the survey measures, we conducted pre-tests (Fowler, 1993), including pilot surveys, interviews and boardroom observations, to assist us in the fine-tuning of the questionnaire and in identifying potentially misleading items (Carpenter \& Westphal, 2001). Moreover, we carefully worded questions to minimize the likelihood of a social desirability bias, using inputs from the pilot interviews. All our questions were close-ended, but to reduce possible common method bias we used both five and seven point scales.

We also performed some of the statistical remedies for common method bias suggested by Podsakoff et al. (2003). First, we used Harman's one factor test. The exploratory factor analysis of the items measuring all perceptual variables exhibits more than one factor with eigenvalues higher than 1.0, thus suggesting that the majority of the variance between the variables cannot be accounted for by one general factor (common method variance). Second, we used the partial correlation procedure to control for the effects of method variance (Lindell \& Whitney, 2001). The results suggest that common method bias does not appear to be a problem in our data. Third and most importantly, in order to enhance the reliability of our measures, we averaged all perceptual measures in the two time points (2004 and 2005) in order to reduce the perceptual bias of the respondent (in our case the CEO).

\section{Variables and Measures}

Both dependent and independent variables are based on multiple-item constructs, and all items were measured through Likert-type scales.

\section{Dependent Variable}


Boards' strategy involvement was measured using four items which represent the different aspects boards of directors are supposed to contribute to in relation to the strategy process. These measures were previously validated in other studies (Minichilli, Zattoni \& Zona, 2009). Accordingly, we used statements about the degree to which the board has been involved in: i) actively initiating strategy proposals; ii) making decisions on long term strategies and main goals; iii) implementing strategy decisions; iv) controlling and evaluating strategy decisions (Minichilli et al., 2009; van Ees, van der Laan \& Postma, 2008). The variable strategy involvement was computed as an index using the mean of these items. CEO responses from 2005 were used. The reason to use 2005 data only was to ensure that the dependent variable could be a result of the independent variables time-wise. The Cronbach alpha for this variable is .92 .

\section{Independent Variables}

The independent variables included in the study are board knowledge, board development and the chairperson's leadership efficacy. While the dependent variable was measured in 2005 only, all independent variables are averaged measures of responses from 2004 and 2005 from the same CEO in order to reduce the perceptual bias. All variables have been computed by harmonizing the 5-points and 7-points Likert scales which were adopted in the 2004 survey and in its 2005 follow-up respectively, and by averaging different items for the three constructs as presented below. For board members' knowledge we used a four-item construct based on Minichilli \& Hansen (2007). The board members' knowledge variable was measured by asking the CEO the extent to which board members have extensive knowledge on aspects such as: i) the activities of the key business functions; ii) the firm's critical technologies and key competences; iii) the firm's products and services; and iv) the 
developments regarding the firm's markets and customer needs. The Cronbach alpha for the final variable is .87 . The board development variable was operationalized as an average of four items in the questionnaire regarding initiatives that improve board interactions and working styles. The board development variable was measured by asking the CEO the extent to which the board of directors made active use of: i) board instructions (including rules for calls and agenda setting); ii) regular board evaluations; iii) regular board development programs; and iv) formal practices to introduce new board members in the board (Long, 2008; Huse, 2007). The Cronbach alpha for the final variable is .72. The board chairperson's leadership efficacy construct was operationalized as the mean of three items related to the board chairperson's way of leading board meetings and board work. The chairperson's leadership efficacy variable was measured by asking the CEO the extent to which the board chairperson was especially skilled in: i) motivating and using each board member's competence; ii) formulating proposals for decisions and summarizing conclusions after board negotiation; iii) chairing board discussions without promoting his/her own agenda (Leblanc, 2005; Huse, 2007). The Cronbach alpha for the final variable is .83 .

\section{Interactions}

As to interaction variables, we computed the following additional variables. Specifically, the variable Chairperson's leadership efficacy*CEO duality has been calculated as a product of the two originating variables, and the chairperson's leadership efficacy variable was mean-centered to avoid collinearity. Similarly, Chairperson's leadership efficacy*Change in board membership has been calculated from the two originating variables, and the chairperson's leadership efficacy variable was mean-centered in this instance. Change in board membership has been computed 
as a dummy variable, with value 1 if at least one board member had changed in the period in between the two survey observations, and 0 otherwise. Computing change in that way makes it a richer variable than computing absolute values in the difference of board membership since it also accounts for substitution effects, that is a board member being replaced by new one thus keeping the total number of board members unaltered, which are common.

\section{Control Variables}

Boards should not be studied without paying attention to its context, and certain contextual variables are frequently used in board research (Zahra \& Pearce, 1989). In this article, we categorize contextual control variables in groups at different levels. At a general level, we controlled for industry characteristics, firm and CEO characteristics; at the board level, we controlled for the so called 'usual suspects' of board research (Finkelstein \& Mooney, 2003).

Industry characteristics potentially influence strategy involvement of boards (Judge \& Zeithaml, 1992; Golden \& Zajac, 2001; Haynes \& Hillman, 2010), and this may be especially evident in high-technology firms (Carpenter, Pollock \& Leary, 2003). Accordingly, we controlled for industry characteristics by using a dummy variable $(1=$ high-tech firm $)$. At firm level, we controlled for firm size, firm age, and also whether the firm is the parent company. Firm size and firm age are among the standard external controls, whereas headquarters are believed to potentially exert an influence on strategy involvement (Brunninge et al., 2007; Huse, 2000). The firm size was measured as number of employees, and a logarithmic transformation allowed adjusting for skewness. Firm age was measured as a logarithmic transformation of the number of years the firm had existed, regardless of its type of incorporation. With respect to CEO characteristics, we controlled for CEO ownership (Gabrielsson \& 
Winlund, 2000; Zahra \& Pearce, 1989; Zahra, Neubaum \& Huse, 2000) and CEO tenure (Boeker, 1989; 1997). These factors are considered to influence board strategy involvement across CEO life cycle evolution (Shen, 2003). CEO ownership was measured as the percentage of shares held by the CEO, while CEO tenure was computed as the number of years the CEO had served in office in the firm. The items refer to the firms' situation at the end of 2004 and all were taken from questions in the survey.

The controls for the 'usual suspects' refer to the traditional board demographic variables used in board research, and include the number of board members (board size), the inside/outside ratio, the board members' shareholding and the CEO duality (Finkelstein \& Mooney, 2003). Board size was measured as the total number of board members (Zahra et al., 2000) with a logarithmic transformation allowing adjustment for skewness. For the inside/outside ratio we computed the insider ratio, measured as the percentage of inside executives over the total number of board members (Mallette \& Fowler, 1992). Board members' shareholding was measured as the ratio of board members' shareholding to total shareholding, and it included shareholding by inside directors (Kosnik, 1987). The variable CEO duality was coded 1 if the CEO was also the chairperson of the board, and 0 otherwise (Finkelstein \& D'Aveni, 1994). Descriptive statistics for all variables are presented in table 1.

- Insert table 1 about here-

\section{RESULTS}

Table 2 shows means, standard deviations, and bivariate correlation coefficients for the variables used in the regression analyses. 
- Insert table 2 about here-

Table 2 shows generally low levels of correlation among the predictors we used for the analyses and the dependent variable. Based on this preliminary analysis, we conducted VIF analysis after each regression to check for multicollinearity. VIF values range from 1 to 3 , thus indicating that multicollinearity is not a problem in our study (Neter, Kutner, Nachtsheim \& Wasserman, 1996).

The hypotheses were tested through hierarchical multiple linear regression analyses. Before running the analyses we examined potential problems in the variables' distribution with respect to the assumptions of hierarchical regression analysis. Residual analyses were conducted, but no results were found that changed the main conclusions. Statistical conclusion validity can be found, but inferences to causal relationship must be done with care when using cross-sectional without longitudinal data. Causal relationships will be discussed in the interpretation of the results. The linear regression analyses were conducted stepwise in order to capture the contribution of each set of variables to the model significance. When testing the hypotheses we thus combined the interpretation of F-change results in the linear regression with the beta coefficients in the models (table 2), and the correlation coefficients displayed in table 2 . The results of the regression analyses are shown in table 3 .

- Insert table 3 about here - 
Model I includes control variables related to firm and CEO characteristics. Model II includes board demographic controls. As expected, the coefficients are weak and aside from industry characteristics (high-tech firm coefficient: .17, $\mathrm{t}=2.05, \mathrm{p}<.05$ ) not significant. Model III includes the board leadership variables, and tests hypotheses 13. As predicted, all three variables are significant with board development (coefficient: .31, $\mathrm{t}=3.61, \mathrm{p}<.001$ ), chairperson leadership efficacy (coefficient: .21, $\mathrm{t}=2.51, \mathrm{p}<.05$ ), and board members' knowledge (coefficient: .20, $\mathrm{t}=2.40, \mathrm{p}<.05$ ) respectively showing the greatest effects on strategy involvement. Thus, hypotheses 1-3 are supported. The interaction between CEO duality and the chairperson's leadership efficacy is introduced in Model IV. The interaction effect is positive (coefficient: .15, t=1.97, $\mathrm{p}<.10$ ) and hypothesis 4 is supported, albeit not as strongly as hypotheses 1-3. The impact of a recent change in board membership is considered in Model $\mathrm{V}$ and the significant negative coefficient $(-.16, \mathrm{t}=-2.16, \mathrm{p}<.05)$ indicates support for hypothesis 5. Finally, Model VI includes the interaction between a recent change in board membership and the chairperson's leadership efficacy. Here, the results indicate that chairperson leadership efficacy positively moderates the negative impact of recent changes in board composition (coefficient: .17, $\mathrm{t}=2.09, \mathrm{p}<.05$ ) and thus hypothesis 6 is supported. As evident from table 2, all models show significant Fsigns (with the exception of model I and II including controls) and adjusted $\mathrm{R}^{2}$ range from .27 (model III) to .36 (model VI). Further, the most significant F-changes are those passing from model II to model III (15.19***), indicating the relevance of board leadership variables. Additionally, the F-changes for the interaction models are significant for all the changes displayed in the table. As table 3 shows, all six hypotheses were fully supported, although with different levels of significance. 


\section{Board Strategy Involvement in Small Firms: Leadership Matters}

We have in this article contributed to the debate about boards in small firms by investigating how board leadership affects boards' strategy involvement. Extant research in small firms has rarely investigated determinants of strategy involvement of boards, despite its acknowledged significance for small firms' performance (Fiegener, 2005). Even fewer studies have investigated leadership in small firm boards, and those tended to focus on structural leadership characteristics (Daily \& Dalton, 1992, 1993). Grounded in a team production perspective, we conceptualised board leadership as a multi-dimensional construct based on group processes and behaviors (Forbes and Milliken, 1999). As we argued, effective board leadership from a team perspective requires both the presence and use of firm-relevant knowledge, which has been recognized as a key characteristic of team production in boards (Kaufman \& Englander, 2005).

Consistent with our predictions, board members' knowledge was shown to have a consistently significant impact on board strategy involvement. This is in line with theoretical arguments, according to which the presence of relevant knowledge at the 
board level is a determinant of board involvement in board tasks, including strategy

(Forbes \& Milliken, 1999). The adoption of a team production perspective, however, suggests that the presence of board knowledge does not imply per se that board members will use their knowledge effectively (Forbes \& Milliken, 1999; Zona \& Zattoni, 2007). Rather, the creation of a process-oriented boardroom culture (Huse, Minichilli \& Schoning, 2005) requires initiatives for board development to be in place (Demb \& Neubauer, 1992; Zahra \& Pearce, 1989). Board evaluations, board instructions and other board development programs are considered to be powerful tools to develop boards. The purpose of such practices is to better understand the challenges of the board work in each firm, facilitate for the board members to get to know each other and thereby enhance the work of the board as a group. Few studies have empirically shown this impact, especially in small firms. Among the few exceptions, Gabrielsson \& Winlund (2000) in their study of Swedish small and medium-sized firms investigated the relationship between formal board evaluations and the boards' service and control involvement, although with inconclusive results.

The investigation of board leadership led us also to indicate board chairperson leadership efficacy as a determinant of constructive team production in the boardroom. As other scholars have already emphasized in theoretical reviews, the chairperson's leadership efficacy can be a determinant of engaged boards (Leblanc, 2005) and our findings provide empirical support. In this perspective, the chairperson is expected to lead other board members in order to develop their cooperative attitude and coalesce the team around common goals and outcomes. This approach goes beyond a more narrow view of leadership that suggests the duties of the board chair are those of hiring, firing and compensating top managers (Coles \& Hesterly, 2000). Rather, it portrays the board chairperson as the most critical person in the boardroom 
who integrates knowledge and develops initiatives to engage board members in team dynamics thus securing effective board leadership. This is in line with a strategic and transformational leadership view of corporate actors which 'glorifies' powerful leaders as opposed to assumptions of the agency theory which 'vilify' these (Cannella \& Monroe, 1997). Along this line, the importance of chairperson leadership efficacy for board strategy involvement is more evident when considering firms with CEO duality. These results are also consistent with what we found for firms experiencing a recent change in board composition: rather than focusing on how a marginal change in an inside vis-à-vis outside board member composition influences firm performance, the team production perspective emphasizes how board leadership matters in securing transitions in team composition.

In summary, we have demonstrated that conceptualizing board leadership as a behavioral and process-based phenomenon has greater explanatory power for small firm boards' strategy involvement than structural leadership characteristics alone. Our findings contribute to the emerging body of knowledge on process-based board research (Daily et al., 2003; Hambrick et al., 2008; Zona \& Zattoni, 2007) by shedding new light on the concept of board leadership in a small firm context. Whilst such leadership in governance may be especially visible and impactful in small firms, our novel theoretical approach also opens new avenues for board research in general.

\section{Implications for Theory: Team Production}

We proposed the team production perspective of the firm as a theoretical lens for studying board leadership. Rather than viewing the firm as a nexus of contracts between principals and agents, with the board tasked with monitoring management on behalf of shareholders, team production theory views the firm as a nexus of firm- 
specific investments with the board acting as the mediating hierarch to control shirking, resolve decision-making and encourage firm-specific investments which all further team production and value creation (Blair \& Stout, 1999).

Whilst Blair \& Stout (1999) developed team production theory at the level of the public corporation, and Kaufman \& Englander (2005) indicated its utility for understanding boards, we used the logic of team production theory to investigate the determinants of small firm boards' strategy involvement. We demonstrated that team production theory can contribute to our understanding of board behavior in several ways. First, at the centre of team production is the board team and the outputs generated by the team, rather than individual directors and their distinctive roles (viz. executive and non-executive). Whilst there have been important contributions to the study of teams in both small business and corporate governance research (Castro et al., 2009; Forbes \& Milliken, 1999; West, 2007), rarely have these been explicitly grounded in team production theory (Gabrielsson et al., 2007). We argue that team production theory provides a complementary theoretical anchor for further conceptual and empirical work at the level of the board team.

Second, in parallel to the team focus, team production theory advances the notion of the mediating hierarch as a means to stimulate team production and resolve decision-making ambiguities (Blair \& Stout, 1999). In governance research, this allows for the simultaneous exploration of the board team and board chairperson behaviors. As our findings have shown, board members' knowledge and skills, board development and chairperson efficacy together had the greatest explanatory power for variations in strategic involvement. Team production theory advances existing studies on the interdependencies of strategic leaders, such as the one by Daily \& Schwenk 
(1996), by its ability to model processes and behaviors related to leadership rather than structural leadership conditions alone, as we discussed above.

Finally, our theoretical approach is complementary to perspectives such as strategic choice (Judge \& Zeithaml, 1992), resource/competence-based views (Zahra et al., 2006) and resource dependency theory (Gabrielsson, 2007) in its emphasis on firm value creation (Huse, 2007). Rather than prioritizing a single actor, as agency theory does in respect of shareholder value, team production theory has at its core the value of the firm per se and recognizes that such value is created by all firm participants, including but not exclusive to shareholders, through the productive use of their firm-specific investments. For board research, team production theory provides an additional theoretical justification for evaluating board performance through its strategic involvement (Pettigrew, 1992; Stiles, 2001).

We argued that the small firm setting is a particularly pertinent one for testing predictions from team production theory because of small firm characteristics including overlapping governance structures, lack of functional managerial competence, strong owner representation in the boardroom and the prevalent internal wealth creation focus (Brunninge et al., 2007; Cowling, 2003). However, as a theoretical lens team production theory may also be useful for studies of the large firm setting and may provide fresh insights into antecedents and consequences of leadership in different governance structures and systems. For example, studies of family businesses in different empirical settings have identified the need to study actor behaviors where non-financial goals are important and not just financial shareholder value (Berrone, Cruz, Gomez-Mejia \& Larraza Kintana, 2010; Zellweger, Nason, Nordqvist \& Brush, 2010), and evidence from international governance research highlights the variety of firm goal orientations (Weimer \& Pape, 1999). 
Team production theory may bring us closer to understanding governance phenomena is such contexts, since it allows a focus on a wider understanding of value creation.

\section{Implications for Practice}

The article has various implications for small firm owners, board members and managers. First, given that board members' firm-relevant knowledge has such a high influence on boards' strategy involvement, the selection of outside board members becomes critical. As such, the assessment of board knowledge should be the mechanism through which owners of small firms make sure that individual knowledge is present, and that it is collectively used by board members through a process of continuous development and learning. Further, it is important also to assess the fit of board members' knowledge with the requirements of the firm's competitive environment, as well as the fit of such collective knowledge with the firm's critical technologies and key products and markets.

A second implication for practice relates to the importance of continuously developing boards in order to create value for firms. Along this line, a belief in the value of board development initiatives permeates most codes of good corporate governance practice (e.g. Higgs, 2003). Board evaluations represent a formal routine that can facilitate a process-oriented boardroom culture (Minichilli et al., 2007). Having such an evaluation system enables a more regular and systematic follow-up of board members' contributions to different board tasks, making it easier to detect inefficiencies and to improve the board work (Lorsch, 1995). It can also help clarify the expectations from each board member and collectively agree the boards' mandate. The role of regular board development initiatives, such as occasional longer meetings, away-days and training seminars for board members is included in several recent 
codes of best practice and promoted by many corporate governance experts (e.g. MacAvoy \& Millstein, 1998).

Although the idea of board development initiatives is not new (cf. Cadbury, 1992), small firms have been traditionally excluded from the debate on board practices, and studies on the cross-national convergence of best practices regarding board functioning traditionally focused on large listed corporations (Aguilera \& CuervoCazurra, 2004). Board development in small firms has instead been limited for a long time to bringing an external member on the board. Nevertheless, the importance of the actual board practices is gaining importance also in small firms, and we may expect relevant developments in the near future.

Finally, owners of small firms should also consider the importance of identifying a strong leadership inside the boardroom. With respect to this, scholars have noted the pivotal role of the chairperson in establishing a process-oriented board climate that stimulates discussion and motivates all board members to use their knowledge and skills in the board's work (Huse, 2005). This study empirically reinforces such theoretical predictions, and suggests to owners and board members that effective leadership has a strong impact on board involvement, and particularly on strategy involvement.

\section{Limitations and Directions for Future Research}

Various directions for further research are possible. First, our results emphasize how certain board working structures and process-oriented boardroom dynamics deserve further research efforts. A potentially fruitful line of inquiry may be to link research in the board process tradition with that of the literature on team and entrepreneurial learning (Holcomb, Ireland, Holmes \& Hitt, 2009; Lumpkin \& Lichtenstein, 2005). 
This may shed further light on how well and how quickly new knowledge is transferred and used in small firms. Second, a cross-sectional associative research design was chosen, although we used observations through a time-window. Further studies should include longitudinal designs, even if the collection of primary data from CEOs and/or chairpersons longitudinally might be quite complex, as our initial attempts have shown. Third, the CEOs were the respondents of the main survey in this study. The results are, as most other survey studies about boards, biased in favor of CEO perceptions, especially regarding his/her perceptions of the leadership efficacy of the chairperson. In the small number of cases where $\mathrm{CEO} /$ chairperson roles were combined, the chairperson leadership efficacy measure is in effect a self-rated one and our findings in respect of hypothesis 4 need to be treated with particular caution. Future studies may also include observations from other board respondents order to validate measures on sub-samples.

Finally, our study is based on 140 firms in Norway. As we already discussed, the number of firms significantly reduced when considering responses for both time periods (2004 and 2005) from identical firms, and the challenge is to increase the number of observations when simultaneously using multiple answers from the same firms in different time periods. Although the Norwegian governance context has many similarities to other countries (Zhang, 2010), there are also differences most notably the regulatory framework, the prevalence of active small firm boards and concentrated ownership structures (Randoy and Goel, 2003). These specificities of the Norwegian context made it a particularly useful empirical setting for our research. However, even though our measures are similar to those from studies in other European contexts (Gabrielsson \& Winlund, 2000; Zona \& Zattoni, 2007) and our findings resonate with studies elsewhere, including Anglo-American countries (Demb 
\& Neubauer, 1992; Forbes \& Milliken, 1999; Leblanc, 2005; Stiles, 2001), there is a need for further research in different empirical settings in order to generalize results.

\section{CONCLUSION}

We have explored how board leadership in small firms may contribute to board strategy involvement. We acknowledge that our study has limitations in respect of its single country setting, the use of CEO responses, and the limited two year observation window. Nevertheless, in taking a novel theoretical approach, we have made an initial contribution to knowledge on the impact of behavioral aspects of board leadership on strategy involvement in small firms. Hypotheses about board members' knowledge, board development and board chairperson leadership behaviors were supported. We also provided evidence that board chairperson leadership is of particular importance under contingent situations, and specifically in firms with CEO duality and following a change in board composition. Our study has implications both for theory and practice, indicating how complementary theoretical approaches, such as the team production theory of the firm, may explain more than traditional board composition and independence models in the context of small firms. Along this line, we provided several suggestions for small business owners and managers who may benefit from strategic involvement of their boards of directors.

\section{REFERENCES}

Aguilera, R.V. \& Cuervo-Cazurra, A. 2004. Codes of good governance worldwide: What is the trigger? Organization Studies, 25(3): 415-443.

Alchian, A.A. \& Demsetz, H. 1972. Production, information costs, and economic organization. American Economic Review, 62: 777-795. 
Anderson, C.A. \& Anthony, R.N. 1986.The new corporate directors. New York: John Wiley.

Arthurs, J. D., Busenitz, L. W., Hoskisson, R. E., \& Johnson, R. A. 2009. Firmspecific human capital and governance in IPO firms: Addressing agency and resource dependence concerns. Entrepreneurship: Theory \& Practice, 33(4): 845-865.

Baysinger, B., \& Hoskisson, R. E. 1990. The composition of boards of directors and strategic control: Effects on corporate strategy. Academy of Management Review, 15(1): 72-87.

Berrone, P., Cruz, C.C., Gomez-Mejia, L. \& Larraza Kintana, M. (2010) Socioemotional wealth and corporate response to institutional pressures: Do familycontrolled firms pollute less? Administrative Science Quarterly, (forthcoming).

Blair, M. \& Stout, L.A. 1999. A team production theory of corporate law. Virginia Law Review, 85: 247-328.

Blair, M. M. 2005. Institutionalists, neoclassicals and team production. British Journal of Industrial Relations, 43(4): 605-616.

Boeker, W. 1989. Strategic change: The effects of founding and history, Academy of Management Journal, 32(3): 489-515

Boeker, W. 1997. Strategic change: The influence of managerial characteristics and organisational growth. Academy of Management Journal, 40(1): 152-170.

Borch, O.J. \& Huse, M. 1993. Informal strategic networks and the board of directors. Entrepreneurship Theory and Practice, 18(1): 23-36.

Brundin, E. \& Nordqvist, M. 2008. Beyond facts and figures: The role of emotions in boardroom dynamics. Corporate Governance: An International Review, $16(4),: 326-341$.

Brunninge, O., Nordqvist, M. \& Wiklund, J. 2007. Corporate governance and strategic change in SMEs: The effects of ownership, board structure and top management teams. Small Business Economics, 29(3): 295-308.

Cannella, A.A. \& Monroe, M.J. 1997. Contrasting perspectives on strategic leaders: Toward a more realistic view of top managers. Journal of Management, 23(3): 213-237. 
Carpenter, M.A. \& Westphal, J.D. 2001. The strategic context of external network ties: Examining the impact of director appointments on board involvement in strategic decision making. Academy of Management Journal, 44: 639-660.

Carpenter, M.A., Pollock, T.G. \& Leary, M.M. 2003. Testing a model of reasoned risk-taking: Governance, the experience of principals and agents, and global strategy in high-technology IPO firms. Strategic Management Journal, 24: 803-820.

Castro, C.B., de la Concha, M.D., Gravel, J.V. \& Perinan, M.M.V. 2009. Does the team leverage the board's decisions? Corporate Governance: An International Review, 17(6):744-761.

Certo, S.T., Covin, J.G., Daily, C.M. \& Dalton, D.R. 2001. Wealth and the effects of founder management among IPO-stage new ventures, Strategic Management Journal, 22: 641-658.

Certo, S. T., Daily, C. M., \& Dalton, D. R. 2001. Signaling firm value through board structure: An investigation of initial public offerings, Entrepreneurship: Theory \& Practice, 26(2): 33-50.

Chahine, S. \& Tohme, N.S. 2010. Is Ceo duality always negative? An exploration of CEO duality and ownership structure in the Arab IPO context, Corporate Governance: An International Review, 17(2): 123-141.

Coles, J., \& Hesterly, W. 2000. Independence of the chairman and board composition. Firm choices and shareholder value, Journal of Management, 26: 195-214.

Collis, D.J. 1994. Research note: how valuable are organizational capabilities? Strategic Management Journal, 15: 143-152.

Conger, J.A., Finegold, D. \& Lawler, E.E 1998. Appraising boardroom performance, Harvard Business Review, 136-148.

Conyon, M. J., \& Peck, S. I. 1998. Board control, remuneration committees, and top management compensation, Academy of Management Journal, 41(2): 146157.

Cowling, M. 2003. Productivity and corporate governance in smaller firms, Small Business Economics, 20: 335-344.

Daily, C.M., \& Dalton, D.R. 1992. The relationship between governance structure and corporate performance in entrepreneurial firms, Journal of Business Venturing, 7: 375-386. 
Daily, C.M. \& Dalton, D.R. 1993. Board of directors leadership and structure: Control and performance implications. Entrepreneurship Theory and Practice, 17: 6581.

Daily, C.M., Dalton, D.R. \& Cannella Jr., A.A 2003. Corporate governance: Decades of dialogue and data. Academy of Management Review, 28: 371-382.

Daily, C.M., McDougall, P.P., Covin, J.G., \& Dalton, D.R. 2002. Governance and strategic leadership in entrepreneurial firms. Journal of Management, 15(5): 128.

Daily, C.M., Schwenk, C. 1996. Chief executive officers, top management teams, and boards of directors: Congruent or countervailing forces. Journal of Management, 22(2): 185-208

Dalton, D.R., Daily, C.M., Ellstrand, A.E., \& Johnson, J.L. 1998. Meta-analytic reviews of board composition, leadership structure, and financial performance. Strategic Management Journal, 19: 269-290.

Davis, P.S. \& Pett, T.L. 2000. Governance and goal formation among family business: A resource dependency perspective. The International Journal of Entrepreneurship and Innovation, 1: 137-149.

Davis, J.H., Schoorman, F.D. \& Donaldson, L. 1997 Toward a stewardship theory of management. Academy of Management Review, 22(1): 20-47.

Demb, A. \& Neubauer, F.F. 1992. The corporate board: Confronting the paradoxes. Oxford: Oxford University Press.

Dess, G. G., Lumpkin, G. T., \& McGee, J. E. 1999. Linking corporate entrepreneurship to strategy, structure, and process: Suggested research directions. Entrepreneurship: Theory \& Practice, 23(3): 85-102.

Doty, D.R. \& Glick, W.H. 1998. Common methods bias: Does common methods variance really bias results? Organizational Research Methods, 1(4): 374-406.

Dillman, D.A. 2000. Mail and internet surveys: The tailored design method, New York: John Wiley.

Dulewicz, V., Gay, K., \& Taylor, B. 2007. What makes an outstanding chairman? Findings from the UK non-executive director of the year awards, 2006. Corporate Governance: An International Review, 15(6): 1056-1069.

Eddleston, K. A. 2008. Commentary: The prequel to family firm culture and stewardship: The leadership perspective of the founder. Entrepreneurship: Theory \& Practice, 32(6): 1055-1061. 
European Union 2003. Definition of micro, small and medium-sized enterprises, Commission Recommendation 2003/361/EC of 6 May 2003 concerning the definition of micro, small and medium-sized enterprises (Official Journal L 124

of 20.05.2003), http://europa.eu/legislation_summaries/enterprise/business_environment/n260 26_en.htm, last accessed $24^{\text {th }}$ October 2010

Fama, E.F. \& Jensen, M.C. 1983. Separation of ownership and control. Journal of Law and Economics, 26: 301-325.

Fiegener, M.K. 2005. Determinants of board participation in the strategic decisions of small corporations. Entrepreneurship Theory and Practice, 29(5): 627-650.

Fiegener, M.K., Brown, B.M., Dreux, D.R. \& Dennis, W.J. Jr. 2000a. The adoption of outside boards by small private US firms. Entrepreneurship and Regional Development, 12: 291-309.

Fiegener, M. K., Brown, B. M., Dreux, D. R., \& Dennis, W. J. 2000b. CEO stakes and board composition in small private firms. Entrepreneurship: Theory \& Practice, 24(4): 5-24.

Finkelstein, S. \& D'Aveni, R.A. 1994. CEO duality as a double-edged sword: How boards of directors balance entrenchment avoidance and unity of command. Academy of Management Journal, 37(5): 1079-1108.

Finkelstein, S. \& Mooney, A.C. 2003. Not the usual suspect: How to use the board process to make boards better. Academy of Management Executive, 17(2): 101113.

Forbes, D.P. \& Milliken, F.J. 1999. Cognition and corporate governance: Understanding boards of directors as strategic decision-making groups. Academy of Management Review, 24: 489-505.

Fowler, F.J. 1993. Survey research methods, Newbury Park: Sage.

Furr, R.M., \& Furr, L.J. 2005. Is your chairman a leader? Corporate Board, 26(154): 11-15.

Gabrielsson, J. 2007. Correlates of board empowerment in small companies. Entrepreneurship Theory \& Practice, 31: 687-712.

Gabrielsson, J., \& Huse, M. 2004. Context, Behavior, and Evolution. International Studies of Management \& Organization, 34(2): 11-36. 
Gabrielsson, J., Huse, M. \& Minichilli, A. 2007. Understanding the leadership role of the board chairperson through a team production approach. International Journal of Leadership Studies, 3(1): 21-39.

Gabrielsson, J. \& Winlund, H. 2000. Boards of directors in small and medium-sized industrial firms: The importance of board member activity and working style on board task performance. Entrepreneurship and Regional Development, 12(4): 311-330.

Golden, B.R. \& Zajac, E.J. 2001. When will boards influence strategy? Inclination x Power $=$ Strategic change. Strategic Management Journal, 22: 1087-1111.

Hambrick, D.C., von Werder, A. \& Zajac, E.J. 2008. New directions in corporate governance research. Organization Science, 19: 381-385.

Haynes, K.T. \& Hillman, A. 2010. The effect of board capital and CEO power on strategic change. Strategic Management Journal, 31: 1145-1163.

Hillman, A. \& Dalziel, T. 2003. Boards of directors and firm performance: Integrating agency and resource dependence perspectives. Academy of Management Review, 28: 383-396.

Hitt, M. A., Harrison, J. S., \& Ireland, R. D. 2001. Mergers and acquisitions: A guide to creating value for stakeholders. New York: Oxford University Press.

Holcomb, T. R., Ireland, R. D., Holmes Jr, R. M., \& Hitt, M. A. 2009. Architecture of entrepreneurial learning: Exploring the link among heuristics, knowledge, and action. Entrepreneurship: Theory \& Practice, 33(1): 167-192.

Huse, M. 1990. Board composition in small enterprises. Entrepreneurship and Regional Development, 2: 363-373

Huse, M. 2000. Boards of directors in SMEs: A review and research agenda. Entrepreneurship and Regional Development, 12(4): 271-290.

Huse, M. 2005. Accountability and creating accountability: A framework for exploring behavioural perspectives of corporate governance. British Journal of Management, 16: S65-79.

Huse, M. 2007. Boards, governance and value creation, Cambridge: Cambridge University Press.

Huse, M., Minichilli, A. \& Schoning, M. 2005. Corporate boards as assets for operating in the new Europe: The value of process-oriented boardroom dynamics. Organizational Dynamics, 34(3): 285-297 
Jensen, M.C. \& Meckling, W.H. 1976. Theory of the firm: managerial behaviour, agency costs and ownership structure. Journal of Financial Economics, 3(4): 305-360.

Johannisson, B. \& Huse, M. 2000. Recruiting outside board members in the small family business: An ideological challenge. Entrepreneurship and Regional Development, 12(4): 353-378.

Judge Jr, W. Q., \& Zeithaml, C. P. 1992. Institutional and strategic choice perspectives on board involvement in the strategic decision process. Academy of Management Journal, 35(4): 766-794.

Kaufman, A., \& Englander, E. 2005. A team production model of corporate governance. Academy of Management Executive, 19(3): 9-22.

Kim, B., Burns, M. \& Prescott, J.E. 2009. The strategic role of the board: The impact of board structure on top management team strategic action capability. Corporate Governance: An International Review, 17 (6): 728-743.

Kosnik, R.D. 1987. Greenmail: A study of board performance in corporate governance. Administrative Science Quarterly, 32: 163-185.

Kumar, N., Stern, L.W., \& Anderson, J.C. 1993. Conducting interorganizational research using key informants. Academy of Management Journal, 36(6): 16331651 .

Leblanc, R. \& Gillies, J. 2005. Inside the boardroom. How boards really work and the coming revolution in corporate governance, Toronto: John Wiley and Sons Canada.

Leblanc, R. 2005. Assessing board leadership. Corporate Governance: An International Review, 13: 654-666.

Letendre, L. 2004. The dynamics of the boardroom. Academy of Management Executive, 18: 101-104.

Lindell, M. \& Whitney, D.J. 2001. Accounting for common method variance in crosssectional research designs. Journal of Applied Psychology, 86(1): 114-121.

Long, T. 2008. Diving for pearls: the importance of board induction and re-induction. International Journal of Business Governance and Ethics, 4(1): 40-50.

Lorsch, J.W. 1995. Empowering the board, Harvard Business Review, JanuaryFebruary: 107-117. 
Lumpkin, G. T., \& Lichtenstein, B. B. 2005. The role of organizational learning in the opportunity-recognition process. Entrepreneurship: Theory \& Practice, 29(4): 451-472.

Lynall, M.D., Golden B.R. \& Hillman, A.J. 2003. Board composition from adolescence to maturity: A multitheoretic view. Academy of Management Review, 28: 416-431.

MacAvoy, P., \& Millstein, I. 2003. The recurrent crisis in corporate governance. New York: Palgrave Macmillan.

Mallette, P. \& Fowler, K.L. 1992. Effects of board composition and stock ownership on the adoption of poison pills. Academy of Management Journal, 35: 10101035.

McNulty, T. \& Pettigrew, A. 1999. Strategist on the board. Organization Studies, 20: 47-74.

Minichilli, A., \& Hansen, C. 2007. The board advisory tasks in small firms and the event of crisis. Journal of Management and Governance, 11(1): 5-22.

Minichilli, A., Gabrielsson, J., \& Huse, M., 2007. Board evaluations: making a fit between the purpose and the system. Corporate Governance: An International Review, 15(4): 609-622.

Minichilli, A., Zattoni, A. \& Zona, F. 2009. Making boards effective: An empirical examination of board task performance. British Journal of Management, 20: $55-74$.

Muth, M.M., Donaldson, L. 1998. Stewardship theory and board structure: a contingency approach. Corporate Governance: An International Review, 6(1): $5-28$.

Nelson, T. 2003. The persistence founder influence: Management, ownership, and performance effects at initial public offering. Strategic Management Journal, 24: 707-724.

Neter, J., Kutner, M.H., Nachtsheim, C.J. \& Wasserman, W. 1996. Applied linear statistical models. Boston: McGraw Hill.

NUES (2010) The Norwegian Code of Practice for Corporate Governance, October 2010 revision issued by the Norwegian Corporate Governance Board, http://www.nues.no/English/The_Norwegian_Code_of_Practice_for_Corporate_ Governancel, last accessed $29^{\text {th }}$ November 2010. 
Pearce, J.A. \& Zahra, S.A. 1991. The relative power of CEOs and boards of directors: Associations with corporate performance. Strategic Management Journal, 12: 235-153.

Pettigrew, A.M. 1992. On studying managerial elites. Strategic Management Journal, 13: 163-82.

Podsakoff, P.M., MacKenzie, S.B., Lee, J.Y., \& Podsakoff, N.P. 2003. Common method biases in behavioral research: A critical review of the literature and recommended remedies. Journal of Applied Psychology, 88: 879-903.

Pugliese, A. \& Wenstøp, P. 2007. Board members' contribution to strategic decision making in small firms. Journal of Management and Governance, 11(4): 383404.

Pugliese, A., Bezemer, P., Zattoni, A., Huse, M., Van Den Bosch, F.A.J., \& Volberda, H.W. 2009. Boards of directors' contribution to strategy: A literature review and research agenda. Corporate Governance: An International Review, 17: 292306.

Randoy, T \& Goel, S. 2003. Ownership structure, founder leadership, and performance in Norwegian SMEs: Implications for financing entrepreneurial opportunities, Journal of Business Venturing, 18(5): 619-637.

Rechner, P.L. \& Dalton, D.R. 1991. CEO duality and organizational performance: a longitudinal analysis. Strategic Management Journal, 12(2): 155-160.

Rindova, V. 1999. What do corporate boards have to do with strategy: A cognitive perspective. Journal of Management Studies, 36: 953-977.

Roberts, J., McNulty, T. \& Stiles, P. 2005. Beyond agency conceptions of the work of the non-executive director: Creating accountability in the boardroom. British Journal of Management, 16: S5-S26.

Sandberg, W. R. 1992. Strategic Management's Potential Contributions to a Theory of Entrepreneurship. Entrepreneurship: Theory \& Practice, 16(3): 73-90.

Schulze, W.S., Lubatkin, M.H. \& Dino, R.N. 2003. Toward a theory of agency and altruism in family firms. Journal of Business Venturing, 18(4): 473-490.

Shen, W. 2003, The dynamics of the CEO-Board relationship: An evolutionary perspective. Academy of Management Review, 28(3): 466-476.

Shleifer, A. \& Vishny, R.W. 1997. A survey of corporate governance. Journal of Finance, 52(2): 737-783. 
Stiles, P. 2001. The impact of the board on strategy: An empirical examination. Journal of Management Studies, 38(5): 627-650.

Stiles P. \& Taylor B. 2001. Boards at work. Oxford: Oxford University Press.

Stinchcombe, A.L. 1965. Organizations and social structure, in J.G. March (Ed.), Handbook of Organizations: 142-193. Chicago: Rand McNally.

Tuggle, C.S., Sirmon, D.G., Reutzel, C.R. \& Bierman, L. 2010. Commanding board of director attention: investigating how organizational performance and CEO duality affect board members' attention to monitoring, Strategic Management Journal, 31(9): 946-968.

Uhlaner, L., Floren, R.H. \& Geerlings, J.R. 2007. Owner commitment and relational governance in the privately-held firm: An empirical study. Small Business Economics, 29(3): 275-293.

Uhlaner, L., Wright, M. \& Huse, M. 2007. Private firms and corporate governance: An integrated economic and management perspective, Small Business Economics, 29: 225-241.

Van den Heuvel, J., Van Gils, A. \& Voordeckers, W. 2005. Board roles in small and medium sized family businesses. Corporate Governance: An International Review, 13: 467-83.

Van Ees, H., van der Laan, G., \& Postma, T.J.B.M. 2008. Effective board behavior in The Netherlands. European Management Journal, 26: 84-93.

Weimer, J. \& Pape, J.C 1999. A taxonomy of systems of corporate governance. Corporate Governance: An International Review. 7(2): 152-166.

West, G. P. 2007. Collective cognition: When entrepreneurial teams, not individuals, make decisions. Entrepreneurship: Theory \& Practice, 31(1): 77-102.

Westphal, J. D., \& Fredrickson, J. W. 2001. Who directs strategic change? Director experience, the selection of new CEOs, and change in corporate strategy. Strategic Management Journal, 22(12): 1113-1137.

Wu, J. B., Tsui, A. S., \& Kinicki, A. J. 2010. Consequences of differentiated leadership on groups. Academy of Management Journal, 53(1): 90-106.

Zahra, S.A. \& Filatotchev, I. 2004. Governance of the entrepreneurial threshold firm: A knowledge-based perspective. Journal of Management Studies, 41(5): 883895. 
Zahra, S., Filatotchev, I. \& Wright, M. 2009. How do threshold firms sustain corporate entrepreneurship? The role of boards and absorptive capacity. Journal of Business Venturing, 24: 248-260.

Zahra, S.A., Neubaum, D.O. \& Huse, M. 2000. Entrepreneurship in medium-sized companies: Exploring the effects of ownership and governance systems. Journal of Management, 26(5): 947-976.

Zahra, S.A. \& Pearce, J. 1989. Boards of directors and corporate financial performance: A review and integrative model. Journal of Management, 15: 291-334.

Zahra, S.A., Sapienza, H.J. \& Davidsson, P. 2006. Entrepreneurship and dynamic capabilities: A review, model and research agenda. Journal of Management Studies, 43(4): 917-955.

Zattoni, A., \& Cuomo, F. 2010. How independent, competent and incentivized should Non-executive directors be? An empirical investigation of good governance codes. British Journal of Management, 21(1): 63-79.

Zellweger, T.M., Nason, R.S., Nordqvist, M. \& Brush, C.G. 2010. Why do family firms strive for non-financial goals? An organizational identity perspective. Entrepreneurship Theory and Practice, (forthcoming).

Zhang, P. 2010. Board information and strategic task performance, Corporate Governance: An International Review, 18(5): 473-487.

Zona, F., \& Zattoni, A. 2007. Beyond the black box of demography: Board processes and task effectiveness within Italian firms, Corporate Governance: An International Review, 15(5): 852-864. 
TABLE 1: Descriptive Statistics for Relevant Variables

\begin{tabular}{|c|c|c|c|c|}
\hline & Minimum & Maximum & Mean & Std. Deviation \\
\hline High tech firm & .00 & 1.00 & .25 & .43 \\
\hline Size (Number of employees) & 5.00 & 50.00 & 22.35 & 15.83 \\
\hline Size (ln employees) & 1.60 & 3.93 & 2.80 & .99 \\
\hline Revenues (Million NOK) & .09 & 1600.00 & 80.49 & 142.57 \\
\hline Firm age & .00 & 162.00 & 30.91 & 31.72 \\
\hline Firm age (Ln) & .00 & 5.09 & 2.95 & 1.01 \\
\hline Firm is the HQ & .00 & 1.00 & .40 & .49 \\
\hline CEO ownership & .00 & 100.00 & 22.81 & 32.59 \\
\hline CEO tenure & .00 & 45.00 & 7.36 & 6.45 \\
\hline Number of board members & 3.00 & 10.00 & 4.41 & 1.33 \\
\hline Board Size (Ln N of members) & 1.10 & 2.30 & 1.44 & .28 \\
\hline Insider ratio & .00 & 1.00 & .33 & .31 \\
\hline Shareholder ratio & .00 & 1.00 & .42 & .37 \\
\hline CEO duality & .00 & 1.00 & .09 & .28 \\
\hline $\begin{array}{l}\text { Board members' knowledge (04- } \\
05)\end{array}$ & 1.96 & 5.00 & 4.12 & .57 \\
\hline Board development (04-05) & 1.00 & 5.00 & 2.74 & .85 \\
\hline Chair efficacy (04-05) & 1.00 & 6.00 & 4.32 & .93 \\
\hline Change in board membership & .00 & 1.00 & .27 & .44 \\
\hline Strategy Involvement 2005 & 1.00 & 7.00 & 4.94 & 1.48 \\
\hline Valid N (listwise) & 140 & & & \\
\hline
\end{tabular}


TABLE 2. Correlation Analysis

\begin{tabular}{|c|c|c|c|c|c|c|c|c|c|c|c|c|c|c|c|c|c|}
\hline & Mean & St.dev. & 1. & 2. & 3. & 4. & 5. & 6. & 7. & 8. & 9. & 10. & 11. & 12. & 13. & 14. & 15 \\
\hline 1. Hi-tech firm & .25 & .43 & 1 & & & & & & & & & & & & & & \\
\hline $\begin{array}{l}\text { 2. Firm size (Ln } \\
\text { employees) }\end{array}$ & 2.79 & .99 & .08 & 1 & & & & & & & & & & & & & \\
\hline 3. Firm age & 2.95 & 1.01 & -.02 & $.33 * *$ & 1 & & & & & & & & & & & & \\
\hline 4. Firm is the HQ & .40 & .49 & -.06 & -.06 & $.16^{* * *}$ & 1 & & & & & & & & & & & \\
\hline 5. CEO ownership & 22.81 & 32.59 & -.05 & -.04 & .03 & $.41 * *$ & 1 & & & & & & & & & & \\
\hline 6. CEO tenure & 7.36 & 6.44 & -.07 & $.14 * *$ & $.29 * *$ & .06 & $.26 * *$ & 1 & & & & & & & & & \\
\hline $\begin{array}{l}\text { 7. Number of board } \\
\text { members (Ln) }\end{array}$ & 1.44 & .28 & -.02 & .06 & $.10 *$ & $-.25 * *$ & $-.22 * *$ & .03 & 1 & & & & & & & & \\
\hline 8. Insider ratio & .32 & .31 & -.01 & .01 & -.05 & .05 & $.16^{*}$ & .05 & $-.25 * *$ & 1 & & & & & & & \\
\hline 9. Shareholder ratio & .45 & .41 & .00 & $-.12 *$ & -.03 & $.18 * *$ & $.28 * *$ & .04 & $-.12 *$ & $.16^{*}$ & 1 & & & & & & \\
\hline 10. CEO duality & .09 & .28 & -.06 & -.08 & .01 & .08 & $.21 * *$ & .03 & -.04 & .07 & $.24 * *$ & 1 & & & & & \\
\hline $\begin{array}{l}\text { 11. Board members' } \\
\text { knowledge }\end{array}$ & 4.11 & .57 & .08 & .02 & -.00 & $.15^{*}$ & $.22 * *$ & .08 & $-.29 * *$ & $.21 * *$ & .09 & $.14 *$ & 1 & & & & \\
\hline 12. Board development & 2.74 & .86 & -.01 & $.29 * *$ & $.22 * *$ & .02 & .02 & $.15^{*}$ & .10 & -.06 & $-.16^{*}$ & -.04 & $.17 *$ & 1 & & & \\
\hline $\begin{array}{l}\text { 13. Chair leadership } \\
\text { efficacy }\end{array}$ & 4.32 & .93 & .00 & .04 & .12 & .01 & -.01 & .06 & -.00 & -.13 & -.11 & .03 & $.24 * *$ & $.37 * *$ & 1 & & \\
\hline $\begin{array}{l}\text { 14. Change in board } \\
\text { membership }\end{array}$ & .27 & .44 & .05 & -.03 & .01 & .03 & -.06 & -.04 & .09 & -.03 & -.05 & -.03 & .02 & .03 & .04 & 1 & \\
\hline $\begin{array}{l}\text { 15. Strategy } \\
\text { Involvement }\end{array}$ & 4.94 & 1.47 & .06 & .02 & .02 & .02 & -.02 & .09 & -.00 & -.11 & -.03 & .02 & $.25 * *$ & $.39 * *$ & $.36^{* *}$ & -.04 & 1 \\
\hline
\end{tabular}

Pearson's product-moment correlation coefficients. 1-tailed: $*<0.05 ; * *<0.01, \mathrm{~N}=140$ 
TABLE 3. Regression Analyses for Strategy Involvement 2005

Firm and CEO characteristics

Hi-tech firm

$\begin{array}{ll}.17 * & .17 \dagger \\ .09 & .08 \\ .05 & .05 \\ .11 & .11 \\ -.18 \dagger & -.15 \\ .13 & .13\end{array}$

.12
-.00
-.03
.11
$-.16 \dagger$
.05

$.14 \dagger$
-.00
-.02
.09
$-.16 \dagger$
.06

.12

$-.01$

Firm size (Ln employees)

Firm age

Firm is the HQ

CEO ownership

CEO tenure

\begin{tabular}{|c|c|c|c|c|}
\hline -.07 & -.01 & -.02 & .01 & -.01 \\
\hline-.11 & -.10 & -.11 & -.07 & -.09 \\
\hline -.07 & -.06 & -.08 & $-.15 \dagger$ & $-.16^{*}$ \\
\hline-.08 & -.09 & -.06 & $-.13 \dagger$ & $-.13 \dagger$ \\
\hline
\end{tabular}

\section{Board demographics}

Number of board members ( $\mathrm{Ln})$

Insider ratio

Shareholder ratio

CEO duality

Board Leadership

H1 Board members' knowledge (04-05)

H2 Board development (04-05)

H3 Chairperson leadership efficacy (04-05)

$\begin{array}{llll}.20 * & .21 * * & .27 * * * & .25 * * \\ .31 * * * & .30 * * * & .31 * * * & .29 * * * \\ .21 * & .19 * & .22 * * & .17 *\end{array}$

Interactions

(Chair leadership quality)

H4 Chair leadership efficacy*CEO duality

$.15^{*}$

H5 Change in board membership

$-.16 * \quad-.19 * *$

H6 Chair leadership efficacy*Change in board

\begin{tabular}{|c|c|c|c|c|c|c|}
\hline $\mathrm{R}$ & .08 & .10 & .34 & .39 & .41 & .43 \\
\hline Adj R2 & .03 & .03 & .27 & .29 & .34 & .36 \\
\hline F (sign) Full model & $1.82 \dagger$ & 1.44 & $4.99 * * *$ & $5.02 * * *$ & $5.99 * * *$ & $6.04 * * *$ \\
\hline F change & $1.82 \dagger$ & .89 & $15.19 * * *$ & $3.89 *$ & $4.65 *$ & $4.37 *$ \\
\hline $\mathrm{N}=$ & 140 & 140 & 140 & 140 & 136 & 136 \\
\hline
\end{tabular}

$+=.10$-level,$*=.05$-level, $* *=.01$-level, $* * *=.001$-level. 